\title{
Alice de La Rochefoucauld - Carlo M. Marenghi (eds.), Education as a Driver to Integral Growth and Peace - Ethical Reflections on the Right to Education, Geneva, The Caritas in Veritate Foundation, 2019, 442 pp.
}

In the context of commemorating the thirtieth anniversary of the Convention on the Rights of the Child, the Caritas in Veritate Foundation has published its twelfth working paper, entitled"Education as a Driver to Integral Growth and Peace - Ethical Reflections on the Right to Education".

Every child has a right to receive life skills, to strengthen his or her capacities, to enjoy the full range of human rights and to promote a culture infused by appropriate human rights values. Education is a mission, enabling every child to develop their personality, self-esteem, self-confidence, talents and abilities and to live a satisfying and dignified life. However, not only do 258 million children and young people worldwide still lack access to education, but childhood is also facing new emerging global challenges with, among other things, the rise of new conflicts and mass migration, environmental change, and digital technology. With the goal of "no one left behind", the International Community approved the 2030 Agenda for Sustainable Development, an update of the Millennium Development Goals, which takes on a rights-based approach. As is known, the Agenda sets Sustainable Development Goal 4 to "ensure inclusive, equitable and quality education, and promote lifelong learning opportunities for all". In the Incheon Declaration adopted at the World Education Forum in May 2015, UNESCO - as the United Nations agency specialized in education was mandated with its partners to lead and coordinate the 2030 Education Agenda. The roadmap for achieving the ten education goals is the 2030 Education Framework for Action, adopted in November 2015, together with the Global Education Monitoring Report, which provides guidance to governments and their partners on turning commitments into action.

The thirtieth anniversary of the Convention on the Rights of the Child (CRC) provides a unique occasion to take stock of the significant progress made since the adoption of the Convention and to celebrate one of its most empowering rights, that of education. The CRC is a milestone in the international human rights legal framework and represents the most widely ratified human rights treaty in history. The Convention is rooted in the fundamental vision that considers children as persons with their own rights and responsibilities to be protected, promoted and respected, recognizing their fundamental human dignity and the urgency of ensuring their wellbeing and development. As foreseen in Article 29 of the CRC, education must be aimed at the development of the child's personality, talents and potential; the child's respect for human rights; the child's respect for his or her parents, cultural identity, language, cultural and country values; and respect for the natural environment. The right to education encompasses 
access that goes beyond formal education and advocates a holistic, ongoing education. It is a catalyst for human development and should prepare the child for a responsible life in a free society. The publication aims to consider and facilitate a debate on emerging and pressing international issues and to offer a guideline for the discussion and negotiation processes already being considered within the United Nations System, and in which the Holy See and representatives of Catholic-inspired organizations are already engaged. Through the contributions from experts engaged in civil society, academia and international organizations, this work achieves a holistic approach in dealing with the issue by integrating an ethical perspective to the right to education and by giving voice to people who, having embraced the duty to shape the youth with a strong and robust consciousness of life, dedicate their lives and careers to the pursuit of quality and inclusive education.

Consistent with the methodology of previous publications, this Working Paper is also divided into two sections. The first, "Education as a Driver to Integral Growth and Peace", provides new insights into the legal framework of education at national, regional and international level; the importance of values education; and the critical issues of addressing both quality in education and inclusive education. For each chapter, a dual approach has been proposed - academic and theoretical — which is then underscored by "voices on the ground" and experts who proactively work to promote the right to education in the field (the majority of whom belong to faith-based organizations).

The second section,"The Church and Education," consists of a collection of selected texts from the Church's engagement in education introduced in two separate articles by Cardinal GiuseppeVersaldi, Prefect of the Holy See's Congregation for Catholic Education and by Dr. Philippe Richard, Secretary General of the Catholic International Education Office. This anthology is certainly not exhaustive and does not aim to reflect the complexity of Catholic social teaching, but highlights the vital role played by the Church in education over the past 2000 years.

After a brief discussion in the Editorial of the limited progress achieved so far towards "quality education for all" (SDG 4), Dr. Quentin Wodon, Lead Economist at the World Bank and Distinguished Research Affiliate at the Kellog Institute, focuses on four goals: (1) to document the impact of education on other development outcomes; (2) to emphasize the need to improve learning apart from schooling; (3) to acknowledge the importance of character education; and (4) to explore the particular contribution of faith-based schools and the issue of partnerships between those schools and national education systems.

Catholic educational institutions - now more than ever - are urged to be places of education for encounter and critical reflection. In order for pupils to dialogue and put solidarity into practice, they need the support 
of a community that is a living witness to these values. Through the case studies and the academic reflections, it emerges that in faithfulness to its original vocation, moreover, Catholic education is called to broaden its horizons beyond the walls of the classroom and the school, endeavouring to work together with families and civil society in all its forms, thus supporting and promoting complete human growth. The 'educating community' is the privileged "place" for a new and efficient education for citizenship. Within this community, young people can grow their conception of freedom as a relational value, that is, as responsibility and solidarity. We must live all of this nowadays within the complexity and the contradictions of postmodern culture, in a humanity that exists within an interdependent community. This demands the obligation of joint responsibility on the part of all, in the face of challenges that threaten our common survival. Consequently, on this thirtieth anniversary of the Convention on the Rights of the Child (1989), the first instance of legitimacy in educational institutions remains, as always, the "centrality of the person", and related human values. Such a focal point is strictly connected to the capacity to immerse ourselves in the horizon of the "planetary interdependence" of human events at our current point in history, as well as to the idea of humanity's very survival. Catholic education, with its specific understanding of the human person, the world, and history, is undoubtedly challenged by today's society to endeavour to overcome any temptation towards ethnocentric egotism, making the awareness of its own identity the condition for its understanding of others and for its respect for diversity. In this regard, Catholic schools, which have always welcomed students from different cultural and religious backgrounds, have a rich tradition of inclusion and acceptance.

Fernando Chica Arellano

Observador Permanente de la Santa Sede ante la FAO, el FIDA, y el PMA arellano@libero.it 